\title{
Mystification of the highest power: A case of Indonesia*
}

\author{
Kh. Rosyadi \\ Trunojoyo University Madura \\ Jl. Raya Telang, Kamal, Bangkalan, Madura, Indonesia \\ (e-mail: khoirul.rosyadi@trunojoyo.ac.id)
}

\begin{abstract}
In 1998, after the fall of the New Order regime, Indonesia passed through a social, political and economic transition, including a change of power. The first power transition happened in 1999, when Abdurrahman Wahid became the President of Indonesia through the Parliament. The election of Abdurrahman Wahid as the President of Indonesia is inseparable from mystification of power (politics) which he started. The article aims at understanding why Abdurrahman Wahid as the President of Indonesia chose the strategy of power mystification. The study is based on the case study approach. The results of the study show that the strategy of mystification of power was chosen by Abdurrahman Wahid for he could use his social status as the grandson of the founder of the Nahdlatul Ulama (NU) - the largest Islamic organization in Indonesia, which was determined by the NU tradition that children or grandchildren of the kiai had privileges. The Javanese understanding of power is different from the European discourse of power due to the fact that the Javanese explanation of power or leadership cannot be separated from social, political and cultural factors of society or community. Different types of leadership and power are results of differences in social and cultural factors and organization of societies. For the Javanese, power is homogeneous by nature and has the same features wherever it appears. The forms of power are expressions of the same reality, derive from the same source and have the same quality: all forms of power are based on the participation in one force pervading the entire universe. Thus, the Javanese considers individuals and groups that gain power as 'containers' that contain a portion of these cosmic forces.
\end{abstract}

Key words: power; mystification of power; Indonesia; interpretations of power; traditional leader; charismatic leader; religious foundations of power

After the fall of the New Order on May 21, 1998 and elections, the General Session of the Assembly (MPR) of Indonesia elected its Chairman to approve the decree of the State Policy Guidelines (GBHN), discuss amendments to the 1945 Constitution, and elect president and his deputy for five years. Despite the importance of other issues, the election of president and his deputy was a thrilling political battle full of intrigues, maneuvers, and lobbying of the competing parties - Habibie of Golkar and Megawati of PDIP. The situation escalated when two parties made claims of Islamist (Habibie) and nationalist (Megawati) ideologies. The former tried to get the votes of Islamist parties such as the United Development Party (PPP), Justice Party (PK), Crescent Star Party (PBB), NU Party (PNU), Nation Awakening Party (PKB), Islamic Ummah Party (PUI), United Islam Party of Indonesia 1905 (PSII), and Indonesian Political Party Masyumi (PPIIM) to confront the nationalist forces.

* C Kh. Rosyadi, 2020.

The article was submitted on 30.04.2020. The article was accepted on 23.06.2020. 
On October 18, 1999, Habibie's opposition to Megawati finally came to an end in the middle of the road, when the report of the in-transition president was rejected by the MPR, which made Golkar understand its position and withdraw its candidate. But Habibie's defeat was not a failure of the Islamist parties in the confrontation with nationalist forces. Habibie's failure did not weaken the Islamist camp; moreover, non-PDIP parties joined forces to make a camp of resistance. Establishment of the Middle Axis is another evidence of the unification of Muslim political forces, which proved the new Islamist-Nationalist polarization. The Middle Axis led by Amien Rais accepted Abdurrahman Wahid (Gus Dur) as a presidential candidate despite his representation of the mainstream Islamic political interests, which did not correspond to political forecasts. This was not only because Abdurahman Wahid was not from the winning party, but also because the traditionalist Islamic organization's leader was supported by Amien Rais, the leader of the modernist Islamic organization that have always been rival of Nahdlatul Ulama (NU). By the way, Gus Dur did not give a definite answer to the question if he was nominated by the Middle Axis - he left the decision to the elderly NU clerics.

On August 31, 1999, the clerics met in pesantren (boarding school) Langitan and advised NU members to perform istikharah (praying to get a direction from God) and istighatsah - to ask God to support Wahid's presidential nomination by the Middle Axis. On September 27, 1999, the meeting of Nahdliyin clerics was held in pesantren Buntet. In addition, kiai Faqih defined Gus Dur's nomination by the Middle Axis as an analogous of the political management of Mu'awiyah in the early Islamic era, who managed to trick Hussein Ibn Ali into travelling from Medina to Irak. That excessive doubt was reasonable since the clerics and members of the NU believed that Gus Dur was a talisman that had magic power and should not be abandoned.

After the Buntet meeting, the elderly clerics kept in contact via istikharah to continue to ask God's guidance on the nomination of Gus Dur. On October 8, 1999, charismatic clerics met again at the office of the NU Executive Board in Jakarta. The clerics, who were called by the political community 'People of Heaven' or 'Axis of Heaven', made a decision: they claimed that all the Nahdliyin ulamas must support a possible reasonable clerical intuition against the nomination of Gus Dur. On October 10, 1999, at Pesantren Langitan, the Nahdliyin elderly clerics held a meeting again and accepted the Middle Axis' presidential nomination on one condition — the decision depended on the political situation. On October 20, 1999, the long-awaited presidential election finally got two main candidates - Gus Dur and Megawati: by closed vote of 691 members of the Assembly, Gus Dur was elected president with 373 votes (Megawati got 313). Megawati, who was a politically convincing possible winner of the president election due to his party's victory, was defeated by a candidate previously never considered a political player. Gus Dur's path to the presidency in a mystical atmosphere made the clerics act as political 'brokers': thus, the TV news often showed how Gus Dur twirled a ring on his right hand — the 'magic ring', a gift of kiai Faqih. The long journey of the 
'People of Heaven' through istikharah, istighosah of millions of Nahdliyin (members of the NU) and the 'magic ring' of kiai Faqih represent mystification of (spiritual) power of Abdurrahman Wahid.

\section{Mystification of power, Javanese Islam, and charismatic leadership}

In general, mystification or mystification is a spiritual and non-discursive approach to the unity with God/central reality of the universe. If this reality is defined as a transcendent God, mysticism is a path to the unity with the transcendent God. However, introversive mysticism is not the only type - there is also extroversive mysticism, in which the subject feels his unity with the universe, with all beings, and this often implies a pantheistic identification of God with all beings. Within this type of mysticism, there are mystical meditative techniques to reach enlightenment, regardless of the concept of divine. Both approaches were accepted in the Western and Eastern tradition [4. P. 652-653].

In the political context, mystification means any action/activity deviating from real political issues, including understanding the concept of power. The term 'political mystification' was introduced by D.A. Rinkes, a Dutch advisor for the East-Indies affairs. In his report to the Government of the Netherlands in 1914, Rinkes explained that Muslims were fond of mystification, which he proved by the widespread mysticism in tarekat schools and, in particular, the political mystification of the SI (Sarekat Islam), a very popular movement of the time, which proclaimed Pangeran Hangabei, the son of His Majesty Susuhunan Surakarta, the protector in 1913. Mystification of Islam meant that religion changed its focus from this world and eternal salvation into emphasis only on the latter for the Sufism groups. At that time, the SI faced the economic competition with Chinese businessmen, and solved this problem politically — the appointment of Pangeran Hangabei attracted many followers

Like the SI, the PKB founded by Gus Dur also practiced political mystification, which is proved by the following its indicators: use of jinn services; plan of taking legislators' oaths' status of clerics as political brokers; personal cult. The masses were no longer supposed to care about political programs of the PKB; instead they were to accept the leader's personal excellence, support his networks with clerics and NGOs, study his genealogy, and other things that placed the leader and kept him at the top of the NU social hierarchy. Gus Dur could be very convincing even for his opponents, for instance, when explaining why the PKB made coalition with the Indonesian Democratic Party of Struggle (PDI Perjuangan) or supported Megawati and Habibie, why he supported Sri Sultan Hamengkubuwono X, and why he oscillated as a presidential candidate. Replacing a political party with a person constituted political mystification. Outside the PKB, Gus Dur also pursued political mystification for he always used kiai as a political broker to make political decisions. Certainly, replacing political rationality with kiai's advices constituted political mystification. 
Javanese Islam has symbols with animistic and Hinduism-Buddhist meanings [24. P. 89], while its values were affected by the Javanese culture [3. P. 20]. The most important figure of Javanese Islam was Sunan Kalijaga - a hero of the Javanese culture that contributed to the syncretic Javanese Islam. Sunan Kalijaga was an ideal example of Javanese Islam, in which Islamic ideas were socialized by the Javanese culture in the $15^{\text {th }}-16^{\text {th }}$ centuries [3. P. 25-29]. Just like Javanese Hinduism-Buddhism, the development of Islam in Java was more influenced by mystical processes related to the Sanskrit terminology — the legacy of the Javanese Hindu era. In Java, one had to reach a peaceful state of mind or even totally empty one before reaching a mystical insight that would lead to the path (ideas of sunyata (emptiness) and Mahayana Buddhism). The legacy of Javanese Hinduism was interpreted by Islam, in particular, ideas of the path and mystical unity. Mysticism was a paramount element of the Javanese Islam piety, but it could only be practiced as a Shari'a-centered piety [24. P. 139].

The most important thing in mysticism of Javanese Islam was to combine meditation and homage to the wali, including the sacralized ancestors. For the Javanese Islam, wali were people who knew and were close to God. Due to their achievements, the wali were given special powers as a gift from God: wali were free from passions, could influence God, were capable of binding and releasing the sacred, of transforming themselves and moving to a distance, of resurrecting raising the dead, reading mind, telepathy, prophecy, of controlling seasons by blessings and of ensuring war victories by spiritual influences [3. P. 165]. The tribute to the wali consisted of a pilgrimage to their graves and played a central role in the mystical piety of Javanese Islam. From Morocco to Indonesia, the tombs of wali were considered sources of blessing and attracted many visitors [24. P. 122].

However, the Javanese Islam piety was also closely related to the most esoteric mysticism. This, the homage to the wali corresponded to the theological understanding of the prophecy, cosmology, and human perfection. Devotional and esoteric dimensions of Sufism were close to the Javanese religious thought, political theory, and popular beliefs about veneration of the dead, blessings, and pilgrimage [24. P. 141]. Followers of Javanese Islam believed that the pilgrimage was an Islamic tradition as long as one did not ask for blessings or gifts from the dead. Most Javanese Muslims took part in the cult of Java wali and considered the sacred tombs as sources of blessings [3. P. 167] due to the revelation of the sacred, or wangsit, kasekten. By revelation, one could communicate with the prophets of Islam which, according to the Javanese tradition, descended to the wali - the beloved of God [24. P. 132].

The concept of kasekten (supernatural powers) of Javanese Islam goes back to Hinduism, especially the idea of magic. Kasekten is a physical substance animating all human beings. There were many different types of kasekten with specific moral characteristics. One of the kasekten goals was to solve personal tasks, the most important of which was to gain power or to defeat any opposition - by fasting (puasa mutih), staying up all night (ruwatan), and meditation [1. P. 87]. 
For Javanese Muslims, keramat (the sacred) was an adjective describing religious achievements of the wali. As a rule, sacredness constituted sacred tombs or shrines for the wali. Wali cultism was a central element of Javanese Islam. Wali had the power to bless and help those who had worldly or religious problems. Sacredness was obtained through a variety of worships such as asceticism and Godfocused meditation including practices of perception known as tarekat (fasting, standing all the night at the river, eating only white rice or wild plants, staying up all night) [3. P. 168]. Many Javanese Muslims believed that the sacred graves were guarded by jinns capable of identifying the purity of pilgrims and expelling those who had no good intention [24. P. 168]. This understanding of mysticism affected and was inherent in the interpretation of political power by the Javanese Islamic community [1. P. 65].

Issues of power mystification cannot be separated from the social understanding of power. There are at least two quite contradictory concepts of power - Western (Europe) and Javanese (Indonesia). According to Anderson: (1) Power is specific - it really exists; it does not rely on the parties that can use it; it is not a theoretical postulate but an existential reality; it is a force that is invisible, mysterious, of divine nature, it animates the universe; it is manifested in every aspect of nature. In the traditional Javanese thought, there was no distinction between animate and inanimate objects for everything has the same invisible power. The concept that the entire universe consists of amorphous energy that creates power established a link between the rural Javanese 'animism' and the urban metaphysical pantheism. (2) Power is homogeneous: all power is of the same type and originates from the same source. (3) The amount of power in the universe is constant, i.e. the universe neither grows nor shrinks. The entire amount of power does not change - only its distribution in the universe may diverse. In political theory, this idea is very important for concentration of power in one place means its reduction in some other place. (4) The power validity cannot be questioned: as all power comes from a single homogeneous source, it overcomes the good-evil questions. According to the Javanese thoughts, it is of no use to question the claim to rule on the basis of power sources distinction (wealth, violence, etc.). Thus, for the Javanese, power is real, homogeneous, of a fixed amount and without inherent moral implications [1. P. 40-49].

According to Suseno [16. P. 98-99], for the Western consciousness, power is a typical social symptom - ability to impose one's will. Power is something abstract that becomes specific only in its causes and effects. Power consists of certain relationships between people or groups, in which one party can win and impose its will. Power appears in diverse forms, such as parental, charismatic, political, physical, financial, and intellectual - depending on the empirical basis. In the Javanese understanding, power is something totally different, and the very word 'power' (English translation) does not really express its meaning. Power is an expression of amorphous divine force that always creatively pervades the entire universe. Power is not a typical social symptom different from natural forces, but 
an expression of cosmic forces that fills the entire universe. Cosmic forces exist everywhere, but there are places, things and people with a higher concentration of forces; therefore, they cannot be defeated and harmed, they are sekti (supernaturally powerful). Forces that make the sekti are called kasekten. Political power is an expression of kasekten; thus, it is not something abstract, a name for the relationship between people or groups; it is the essence and divine basis of the whole reality. Power can be obtained through mystical practices, yoga, and extreme asceticism, the central underlying idea of which is to collect the initial force [1. P. 49-50].

According to Weber, the Javanese concept of power corresponds to charismatic leadership, i.e. the one whose followers are blindly loyal, committed and obedient due to some personal features of the leader and not his certain abilities or positions. Thus, such leader's powers are unique (inherent talent or fate, revelation, spirituality or sacred qualities) and cannot be transferred to others [15]. For their followers, charismatic leaders constitute an identification image and hopes for a better life; they are saviors and protectors. This is a quite theological leadership based on the idea of the gift of power as coming from the power of God. Moreover, the term 'charismatic' refers to the individual qualities untypical for ordinary people, which makes them believe that the leader has supernatural powers from God [23]. This makes the community or followers uncritical to leaders and their teachings.

Usually, charismatic leaders appear at the times of chaos - this situation makes people choose leaders that are expected to solve all problems; charismatic leaders are closer to the authoritarian and irrational type, although they can be democratic. Charismatic leadership is typical for traditional communities for they are highly homogenous in beliefs, worldviews, cultural values and similar lifestyles. This homogeneity creates a collective consciousness, the same lifestyle, direct and faceto-face relationships, and there is no impersonal division of labor [8. P. 81-82]. This helps charismatic heritage to be institutionalized in a permanent and stable system of social rules [12] through routinization of charisma with the following mechanisms: search for new charismatic leaders who meet the criteria for positions of power; transformation of revelation from extraordinary individuals to their successors by different selection techniques including a formal endorsement; the charismatic leader can directly appoint his successor from his followers; this appointment can be made by agreement of experts from the community; charisma is obtained by descent, so it is limited to relatives; charisma can be found in new individuals outside the kinship system. Charismatic routinization is intended to prevent prolonged crises of leaderships and ensure social stability and harmony [22].

\section{Kiai, santri, charisma and traditional Islam}

Leadership of charismatic type was an important variable that helped to develop the mystification culture of traditional Islam. In pesantren, kiai is charismatic as the center and source of power and authority [2. P. 56]. The greater the charisma of the kiai, the greater his influence on people [5. P. 212]. The word kiai in Javanese defines three different titles: a title of honor for something sacred (for instance, Kiai Garuda 
Kencana is the name of the Gold Train in the Yogyakarta Palace); a title of honor for the elderly in general; a title given by the society to the ulama who become leaders of pesantren and teach classical Islamic scriptures [2. P. 55].

Concerning the word santri, there are at least two interpretations. The first considers santri as derived from the Sanskrit word sastri - literacy. In the past, especially at the beginning of the growing political power of Islam, the santri were literate due to their religious knowledge (could read in Arabic), i.e. santri could recite the Qur'an. The other interpretation considers santri as derived from the Javanese word cantrik - a person who always followed his guru to learn from him. There is still such apprenticeship today but not as 'intense' as before. The pattern of guru-cantrik continued in the period of Islam and turned into guru-santri. Although the word 'guru' was still widely, for leading gurus it was changed by kiai with a sense of sacralization for the elderly. Thus, kiai did not only meant old (like sheikh in Arabic), but also sacred and supernaturally powerful [10. P. 19-20].

Not everyone could achieve the status of kiai. There are some requirements essential to become a kiai: (1) practicing the mastered discipline - the kiai (ulama) should both have and use knowledge; his action and behavior must not contradict what he says; (2) preaching the mastered discipline - the kiai must preach and popularize his discipline to provide the public with information and guidance; (3) complete subjection to the Qur'an - God's and His Prophets' guidance; (4) awareness of the certainty of God's promises and provisions - the kiai must not forget his responsibility as a kiai, which consists of overcoming social problems with all his efforts; (5) being tawadlu' (submissive) and humble — the kiai understands and appreciates the signs of God's Oneness and greatness, accepts his limitations and weaknesses before God, respect others more than being respected by them [9. P. 30-32].

The nahdliyin set criteria for someone to be called kiai: the basic norm is piety to God; the main task is to inherite the mission (treatise) of the Prophet Muhammad in speech, knowledge, teachings, deeds, behavior, mentality and morality; the main characteristics are worshipping diligently, practicing asceticism, mastering eschatology, and devoting all his knowledge to God with great intentions [9. P. 32]. In addition, traditional Muslims believe that kiai are ordinary people that possess spiritual abilities such as karamah (virtues of mind and charisma) and barakah (generosity or mercy) of God which they can share [2. P. 70], which makes most of them charismatic leaders [2. P. 71]. However, this works as long as the kiai is wira'I - refraining from the prohibited — and makruh — clear from anything not permitted by Islam. Thus, the kiai occupy the central position in traditional Islamic communities, play the role of a mediator of the fate of ummah and God, present an example of the ideal Muslim [5. P. 232]. Kiai is the king, and santri are subjects to his power and authority without any conditions and limits - sami'na wa ato'na (we hear and obey) [9. P. 35]. Due to his magical powers, the kiai is to bring good luck (blessings) to the santri (community) and also harm (malati) as punishment for disobedience and bad deeds [10. P. 23-24]. 
The traditional Islamic community shows respect and obedience not only to the kiai but also to all members of his family, including his children. This respect and obedience are absolute and must be a part of the whole lifetime of the community. This absolute respect must be shown in all aspects of life. Ignoring the ties with guru is considered a great disgrace, which eliminates the guru's blessing and makes the knowledge of the santri useless. Even if the guru died, santri must show respect by keeping in touch with the boarding school of the guru and respect his children [2. P. 82]. A child of kiai is a gus (a noble) and deserves all the due respect [10. P. 24]. Gus has a great significance for the pesantren's education system: if he decides to continue studies in other pesantren or community, he will receive special attention and treatment [2. P. 70].

There is no doubt that any santri is expected to ger the guidance of the scripture in his attitude to the kiai. Besides the legitimacy of the doctrine (scriptures), adherence of students (community) to the kiai and his children is also based on the genealogical charisma. Charisma in the NU depends on the charisma of father and other predecessors, and it is also influenced by the charisma of teachers. The leading kiai has at least three or four well-known ulama in the family genealogy [21. P. 152].

According to the legitimacy of the academic doctrine of pesantren and genealogy of the kiai, Abdurrahman Wahid was an ideal, perfect member of the traditionalist Islamic community. In his genealogy, Gus Dur was considered an extraordinary man — with linuwih (supernatural) ability as the wali; he was untouchable, free from the law and public logic [11]. In the NU, Gus Dur was a sakti mandraguna (supernaturally invulnerable) figure who received revelation of power [7]. In terms of the genealogy of the kiai, Abdurraman was a nobleman. Gus Dur was the grandson of Kiai Haji Muhammad Hasyim Asy'ari, the founder of the NU and Pesantren Tebuireng of Jombang. Hasyim Asy'ari was respected for his knowledge and spirituality. Clerics of all Java gave him the title hadratussyaikh the 'great master teacher.' The hadratussyaikh was born in the respected family in a village near the town of Jombang, East Java, in 1871. Kiai Asy' ari, his father, was the founder of Pesantren Keras. Kiai Usman, his grandfather, was known as the leader of Pesantren Gedang that attracted santri from all Java in the late $19^{\text {th }}$ century. Kiai Usman was a leader of tarekat that attracted thousands of followers. And finally, the father of his grandfather, Kiai Sihah, was the founder of Pesantren Tambak Beras in the village on the western outskirts of Jombang [2. P. 92].

The hadratussyaikh took a remarkable spiritual journey: he was a student of then famous ulama such as Kiai Cholil of Bangkalan and Shaykh Mahfudh at Tarmisi of Mecca. In 1899, he returned from Mecca and founded Pesantren Tebuireng. Kiai Hasyim Asy'ari had several children, including Wahid Hasyim who served as the Minister of Religious Affairs in the early days of Indonesian independence and married the eldest daughter of Kiai Bisri Syansuri - a very influential man in the NU. Abudurrahman Wahid was their son, i.e. the grandson of the two founders of the NU and, thus, was entitled the Gus Dur [21. P. 157]. 
Based on the above doctrine and genealogical ties, there is an interaction model called by Scott the patron-client relationship of kiai-santri — an exchange relationship between two roles, in which an individual with a higher economic status (patron) uses his influence and resources to provide protection or benefits to other individuals with a lower status (client); while the client is obliged to pay back by support and assistance, including personal services to the patron [14. P. 7-8]. Certainly, the kiai is the patron because he has absolute authority and power in the institution of pesantren. No one would oppose the kiai except other kiai with greater power and authority [1].

There are three elements that determine the formation of the patron-client relationship like kiai-santri: unequal exchange that reflects differences in statuses - the client (santri) receives a lot of services from the patron (kiai), which obliges the client; patron-client relationship is personal - the personal reciprocity of kiai-santri creates a sense of trust and dependence (the culture of respect of the kiai tends to turn into their cult); the patron relation is comprehensive, flexible and unlimited in time fie to the corresponding socialization of the santri (the santri do not argue with the kiai on any issues because he fears to be cursed).

Abdurrahman Wahid is a part of power mystification as a Javanese Muslim: in Javanese Islam, in which the influence of Hindu-Buddhist animism is dominant, the mystic is the main characteristic of the pious spirit. The Javanese-Islamic mysticism is coherent with the concept of the existing social-political reality. For the Javanese people, power is a supernatural force reflected in the divine power. Political power is an expression of the kesakten; therefore, power is homogeneous and certain. To get power, one must exercise mystical practices, yoga, and extreme asceticism.

Gus Dur was born and raised in the Javanese culture - in Jombang, East Java. In the early days of Islam, Jombang was famous for its abangan tradition. Although Gus Dur was educated in the Middle East and within the Western discourse, his feelings were still determined by the Javanese cultural framework, which was increasingly reinforced by the Islamic tradition (Nahdliyin). Certainly, Abdurrahman Wahid was affected by the Nahdliyin culture for his grandfather Hasyim Asy'ari was the founder of the NU, and Gus Dur was the Chairman of the PBNU. Therefore, Gus Dur belongs to the aristocratic circles of the traditional Islamic community characterized by the mystical thinking (Javanese Islam).

Another Gus Dur's political mystification is the use of the kiai as political brokers. Gus Dur believes that the kiai are representative of heavens, who possess kelinuwihan (supernatural capacity); therefore, they are karomah (people with great morals and charisma) and barokah givers (of grace and virtues from the Lord). They are the beloved people of the Lord and can ask the One of anything including political power. The kiai agree to serve as mediators between Gus Dur and the Lord because he is known as the kiai in the Nahdliyin community. In addition, Gus Dur comes from the noble family: his father was a great kiai and minister; his grandfather, hadratussyaikh (tuan guru), was the great ulama and the founder of 
the NU. Therefore, the sincerity of the kiai to pray for Gus Dur's power is a form of homage to his grandfather. In the NU tradition, the kiai must be respected at all times, including his children after he passed away. This is a unique patron-client relationship of the traditional Islam.

In playing their mystical role, the kiai who became Gus Dur's political brokers relied on their concept of power — both supernatural and physical; it can be achieved not only with political lobbying and coalitions of political parties, but also with supernatural faith. The logical consequence of the supernatural-physical power is that it must be assessed by both people and God: since power is people's mandate, it must be used for the benefit of people and the country standing on God's truth. This concept of power emphasizes the inner and outer balance: the Nahdliyin members follow al-Maturidi theology that combines Jabariyah (ideology saying that what happens to man is the will of God) and Qodiriyah (ideology saying that what happens to man is the result of his deeds).

\section{References}

[1] Anderson B.R. O'G. Language and Power, Exploring the Political in Indonesia. Yogyakarta; 2000.

[2] Dhofier Z. Pesantren Tradition: Studies of Kiai's Worldviews. Jakarta; 1994.

[3] Geertz C. Abangan, Santri, Priyayi in Javanese Societies. Jakarta; 1981.

[4] Good L. Dictionary of Philosophy. Jakarta; 1996.

[5] Horikoshi H. A Traditional Leader a Time of Change: The Kijaji and Ulama in West Java. Jakarta; 1987.

[6] Husain Haikal M. History of the Life of Muhammad. Jakarta; 1989.

[7] Jatman D. Gus Dur's circus of diplomacy. Tajuk. March, 2000.

[8] Johnson D.P. Theories of Classical and Modern Sociology. Jakarta; 1986.

[9] Kacung M. Quo Vadis NU, After Returning to the 1926 Khittah. Jakarta; 1992.

[10] Madjid N. The Chambers of Pesantren: A Portrait of Travel. Jakarta; 1997.

[11] Mulkhan M.A. Trust. Kompas. September 16, 2000.

[12] Nikulin A.M., Trotsuk I.V., Wegren S.K. The importance of strong regional leadership in Russia: the Belgorod Miracle in agriculture // Eurasian Geography and Economics. 2017; 58 (3).

[13] Reinhard B. Max Weber: An Intellectual Portrait. New York; 1962.

[14] Sartono K. Social Dimensions of Leadership. Jakarta; 1990.

[15] Scott J.C. The Peasants' Resistance: Yayasan Obor Indonesia. Jakarta; 1993.

[16] Stephen C.J., Tori H.L. Organizational Behavior. New York; 1997.

[17] Suseno F.M. Javanese Ethics: A Philosophical Analysis of Javanese Life Wisdom. Jakarta; 1999.

[18] Timashev N.S. The phenomenon of power. Methodological Works: 1920-1930. Moscow; 2010 (In Russ.).

[19] Trotsuk I. Discursive construction of social reality: Conceptual foundations and empirical devices for unmasking the "abominable" practices. Sotsiologicheskoe Obozrenie = Russian Sociological Review. 2014; 13 (2) (In Russ.).

[20] Trotsuk I. Too many Webers for small sociology; or, How critically sociologists should consider their canon. Sotsiologicheskoe Obozrenie = Russian Sociological Review. 2019; 18 (2).

[21] van Bruinessen M. Traditionalist Muslims in a Modernizing Society: The NU and Indonesia's New Order Politics, Fictional Conflict, and the Search for a New Discourse. Yogyakarta; 1994.

[22] Weber M. Economy and Society. Los Angeles - London; 1978.

[23] Weber M. The Theory of Social and Economic Organization. New York; 1964.

[24] Woodward M.R. Javanese Islam: Normative Piety, Religious Mysticism. Yogyakarta; 1999. 
DOI: $10.22363 / 2313-2272-2020-20-3-498-508$

\title{
Мистификация высшей власти: индонезийский кейс*
}

\author{
Х. Росьяди \\ Университет Труножово Мадура \\ Райя Теланг, Камал, Бангкалан, Мадура, Индонезия \\ (e-mail: khoirul.rosyadi@trunojoyo.ac.id)
}

В 1998 году, после падения так называемого «нового порядка», Индонезия начала свой долгий путь через череду социальных, политических и экономических трансформаций, включая и транзит власти. Первый такой транзит случился в 1999 году, когда Абдуррахман Вахид стал Президентом Индонезии в ходе парламентского голосования. Автор полагает, что избрание Абдуррахмана Вахида Президентом Индонезии принципиальным образом связано с той мистификацией политической власти, которую он целенаправленно начал и последовательно проводил на протяжении всей своей политической карьеры. Статья призвана ответить на вопрос, почему и как Абдуррахман Вахид, даже занимая уже пост Президента страны, продолжал реализовывать стратегию мистификации своей политической власти. Исследование основано на тактике кейсстади, которая позволила увидеть, что стратегия мистификации власти была выбрана Абдуррахманом Вахидом потому, что он мог использовать свой социальный статус внука основателя партии Нахдатул Улама - крупнейшей мусульманской организации Индонезии, поскольку в ней сохранялась традиция предоставления всевозможных привилегий детям и внукам киаев. В целом яванское понимание власти существенно отличается от европейского дискурса, поскольку индонезийская трактовка власти или лидерства не отделяет его от социальных, политических и культурных факторов, определяющих жизнь общества и сообщества. Соответственно, разные типы лидерства и власти воспринимаются как результаты различий в социальных и культурных факторах, а также в социальной организации разных обществ. Иными словами, власть считается гомогенной по самой своей сути и обладает едиными неизменными качествами, где бы они ни проявлялась. Все формы власти выступают как отражения одной и той же реальности, проистекают из одного источника и имеют одни и те же характеристики, поскольку все они основаны на одной и той же силе, что пронизывает всю вселенную. Таким образом, яванская трактовка власти утверждает, что отдельные люди и группы есть лишь «сосуды», вмещающие в себя определенные порции космических сил.

Ключевые слова: власть; мистификация власти; Индонезия; интерпретации власти; традиционный лидер; харизматический лидер; религиозные основания власти

\footnotetext{
* (с Росьяди Х., 2020.

Статья поступила 30.04.2020 г. Статья принята к публикации 23.06.2020 2.
} 